\title{
Motivational versus Volitional Mediation of Passivity in Institutionalized Older People
}

\author{
Pedro M. Mateos, Juan J.G. Meilán, and José M. Arana \\ University of Salamanca
}

The relationship between perceived loss of control and passivity in social activities in a non-handicapped institutionalized elderiy population was assessed. Perceived loss of control was assessed from three different types of expectancies: low action-outcome expectancies, high situation-outcome expectancies, and low efficacy expectancies. Passivity scores were reported by the staff. The effect of these three types of expectancies on passivity was analyzed in terms of motivation and volition, which were treated as mediating variables. Overall analysis of the structural equations, as well as partial hierarchical regression analyses. showed that efficacy expectancies were good predictors of passivity. but this was not the case for the action-outcome and situation-outcome expcctancies. These results lend more support to a volitional rather than to a motivational interpretation of the effect of control on passivity. The implications of these resuits for intervention and for a differentiated conception of expectancies are discussed.

Key words: montation, volition, aging, conmol

\begin{abstract}
Se evaluó la relación entre pérdida de control percibido y pasividad en actividades sociales en una población de personas mayores institucionalizadas no discapacitadas. La pérdida de control percibido se evaluó a partir de tres tipos diferentes de expectativas: bajas expectativas de acción-resultado, altas expectativas de situación-resultado y bajas expectativas de eficacia. El personal proporcionó las puntuaciones de pasividad. Se analizó la influencia de estos tres tipos de expectativas sobre la pasividad en términos de motivación y wolición, que se consideraron variables mediadoras. El análisis global de ecuaciones estructurales y los análisis de regresión jerárquica parçiales mostraron que las expectativas de eficacia eran un buen predictor de la pasividad, no asi las expectativas de acción-resultado y de situación-resultado. Estos resultados apoyan una interpretación volitiva más que motivacional del efecto del control sobre la pasividad. Se comentan las implicaciones de estos resultados para la intervención y para una concépción diferenciada de las expectativas.

Palabras clave: motivación, volición, envejecimiento, control
\end{abstract}

Comespondence conceming this article should be addressed to Pedro M. Mateos. Departamento de Psicologfa Básica. Psicobiologiat y Metodología. Universidad de Salamanca. Avoja. de la Mered, i09-131. 37005 Salamanca (Spain). L-mail: pmateos@lusal.es 
Contrary to the traditionally maintained view of older people as a homogencous human group, the current outlook highlights the considerable degree of heterogencity in the processes of aging and longevity. This new point of view has generated wide-ranging empirical research into the biological, generational, social. and psychological factors involved in the differential rhythms of aging (See reviews in Baltes \& Baltes, 1990; Maddox \& Lawton, 1988; Nelson \& Danncter, 1992).

Among the psychological factors of accelerated functional losses in aging, loss or deprivation of control has received the most attention from researchers. This interest stems from a serics of studies carricd out in the late seventies with institutionalized older people (e.g., Rodin \& Langer. 1977: Schulz. 1976). The results revealed the negative effects of deprivation of control on both physical and psychological well-being. Older people who were experimentally induced to have greater control over their lives improved considerably in physical health and psychological well-being and a pronounced decrease in mortality rates was observed. Since then, a lirge number of correlational and experimental works have broached the study of the parameters and the conditions involved in this relationship (for recent works, see Chen, 2001; Chou \& Chi, 2001; Krause \& Shaw, 2000; Shaw \& Krause, 2001). All of this has generated much debate on the interpretations of the phenomenon (sce reviews in Arbuckle, Pushkar, Chaikelson, \& Andres, 1999; Baltes \& Baltes, 1986; Fry, 1989; Perrig, 2000; Rodin \& Timko, 1991).

As Kuhl (1986) pointed out, there seems to be a common implicit notion in these works, observed in the following causal chain of events: (a) deprivation of control, (b) perccived loss of control, (c) motivational deficit, (d) performance deficil, (e) accelerated aging. This sequence, which assumes a motivational mediation between perceived control and performance, may have been accepted rather uncritically. The present study offers an empirical analysis of phases $b, c$, and $d$ of this sequence. In particular, we have attempted to analyze the relationship between perceived control and activity-passivity in institutionalized older people, as well as the allcged motivational mediation of this relationship.

The first problem in this analysis involves the dimensionality of control. It has become increasingly clear that the construct of perceived control is not unidimensional (e.g., Abeles, 1991: Lachman, 1986). The construct of control has been defined in different ways by different investigators, leading to confusion as regards both concepts and the measurements used to define them. In an integrative revision, Skinner (1996) cmphasized that any conceptualjzation of control must take into account both beliefs regarding agent-means relations and beliefs regarding means-cnds relations. An agent-means belief relates the self - as an agent-10 the bellavior required to attain the desired outcome. Means-ends belicfs relate either the behavior itself or the situation-as a means to achieve (or alvoid) the desired (or undesired) outcome- to the result or outcome. Control can thus be defined by three types of expectancies: efficacy, action-outcome, and situationoutcome. Whereas Bandura $(1977,1986)$ differentiated between the first two, Heckhauscn (1977) differentiated between the second two.

Based on the above classification of expectancies, we refer to perceived loss of control when: (a) Efficacy expectancies $\left(E_{\text {eff }}\right.$ ) are low (the lack of resources or opportunities causes older people to belicve that they are incapable of performing the necessary action to achieve the desired outcome); (b) Action-outcome expectancies $\left(\mathrm{E}_{\mathrm{a}-\mathrm{o}}\right)$ are low (older people do not belicve that their action will produce the desired results; that is, they do not believe that there is a contingency between their action and the outcome); (c) Situation-outcome expectancies $\left(\mathrm{E}_{\mathrm{s}-\mathrm{r}}\right)$ are high (older people believe that the situation will lead to the desired outcome even if no action is performed).

Even though all three forms of perceived control affect behavior, they cannot be expected to do so by means of the same mechanisms. Using different theoretical frameworks, we propose two possible mediations between perceived control and behavior: motivational mediation and volitional mediation. More specifically, we propose a motivational mediation between low $E_{i-\infty}$ and passivity and a volitional mediation between low $E_{\text {eff }}$ and passivity. We have no theoretical interpretation concerning the mediation between high $\mathrm{E}_{\mathrm{s}-\mathrm{l}}$ and passivity.

The above-mentioned motivational mediation seems evident in the case of loss of control through low $\mathrm{E}_{\mathrm{at}-\mathrm{o}}$. In the so-called expectancy-value motivational models (Feather, 1982), motivation depends on the $E_{\mathrm{a}-\mathrm{o}}$ and on the values assigned to the outcome. Thus, low $\mathrm{E}_{\mathrm{a-o}}$ could have negative effects on behavior as motivation decreases. In fact, for $E_{1-0}$ to have an effect on behavior, the expected outcomes must be important and relevant. Therefore, strictly speaking, the product of low $\mathrm{E}_{\mathrm{a}-\mathrm{0}} \times$ the value $\left(\mathrm{E}_{\mathrm{a}-\mathrm{o}} \times \mathrm{V}\right)$ is what can have negative effects on motivation and behavior. That is, motivational mediation of passivity implies lack of interest in engaging in some kind of behavior, which in turn is based on low valuation of the consequences anticipated from such behavior and the scant subjective likelihood of those consequences resulting from the behavior in question.

Low $E_{e f f}$ can also have negative effects on behavior. However, the idea of self-efficacy as used by Bandura (1977, 1982) — confidence in one's own abilities - has been linked more to notions of self-regulation and volition (Bandura, 1991; Karoly, 1993) than to motivation. Since Heider (1958), many theorists have analyzed behavior in terms of these two variables: motivation (Try) and confidence in onc's own capacity $(C(n)$. The theory of planned behavior developed by Ajzen (1988; sec also Ajzen \& Madden, 1986) provides a broader theoretical framework that relates these constructs. 
Intention, defined as the individual's disposition to attempt to engage in a certain type of behavior, is a key concept of the theory of planned behavior. Intention is an immediate antecedent of the actual behavior. In turn, intention depends on several parameters, two of which are attitude lowards the behavior and perceived behavioral control, which are similar to the constructs of motivation and self-efficacy, respectively.

However, the theory assumes that intention alone is not sufficient to determine behavior when not under total volitional control. This situation can become especially frequent in old age. For an intention to be carried out, the individual must have the necessary personal resources, and the right circumstances must prevail. Otherwisc, self-efficacy (the prospective estimation of the difficulty in dealing with possible impediments) is considered to be a direct predictor of behavior, in addition to intention. To predic behavior, the estimation must be as similar as possible to the rcal difficulties and problems involved in carrying out the behavior. This overall belief in self-efficacy is based on more specific beliefs about resources and opportunities: the efficacy expectancies themselves. Similarly, motivation or attitude towards a behavior are based on more specific belief's about the probability and desirability of achieving certain results by means of that behavior: what is referred to as $\mathrm{E}_{\mathrm{a}-\mathrm{o}} \mathrm{x} V$.

According to the planned behavior theory and to recent theoretical developments in European motivation psychology (Gollwitzer, 1991, 1993; Heckhausen, 1991; Kuhl, 1985; for a review, see Mateos, 1996), passivity can be more the result of volitional deficits (anticipation of a high level of difficulty) than of motivational deficits (little interest in the activity). Therefore, the problem of older people may not be forming intentions but rather, once formed, carrying them out. This volitional mediation has received little attention in research on control and passivity in old age.

Lastly, high $\mathrm{E}_{s-0}$ can also have negative effects on behavior. As in the case of $E_{a-0}$, the expected outcomes (in this case, from the situation itself) must be important and relevant. Therefore, strictly speaking, negative effects on behavior can be expected from a high $E_{\mathrm{s}-0} \times$ value $\left(\mathrm{E}_{\mathrm{s}-0} \times \mathrm{V}\right)$. Some high $E_{s-0}$ may be characteristic of the institutional environment, in which the staff attends to and rewards dependent behavior more than independent behavior (Baltes \& Reisenzein, 1986). In this sense, rather than a loss of control, this is passive or secondary control (Rothbaum, Weisz, \& Snyder, 1982; SchulL, 1986; Wrosch, Heckhausen, \& Lachman, 2000), characterized by accommodative modes of coping (Brandtstädter \& Renner, 1990).

As regards mediation, there is no theoretical basis from the point of view of motivation psychology for the notion that high $E_{s-6}$ may affect behavior motivationally. Nor are there clear predictions for volitional mediation. Battes \& Reisenzein (1986) found that dependence could coexist with high expectancies, of both the $\mathrm{E}_{\mathrm{a}-\mathrm{o}}$ and the $\mathrm{E}_{\mathrm{eff}}$ types.

Research has shown that older people's feelings of control are quite specilic to the various periods of life (Krause, 1994;
Nurmi, Pulliainen, \& Salmela-Aro, 1992; Schulz, Hockhausen, \& Locher, I991). Accordingly, instead of making a global estimation of the degree of activity, we chose a more specific measurcment relating to the area of social contact. Our definition of activity is determined by the particular characteristics of older people (described in the following section and their possibilities for remaining occupjed during their free time in the institution in which they live.

Regarding how available free lime is employed, passive behavior, such as wandering in the hallways, staying in rooms, or dozing in the armchairs on the main floor, is frequent. In this context, activity (in the social rather than in the physical sense) is defined as going to meeting rooms where some type of contact or social interaction may take place. Among the activities carried out in the institution, there were two that specially favored social contact among the residents: going lo a reading room equipped with newspapers and magazines, and attending showings of videos as a group on weekends.

Other studies have shown that these types of activities arc positively valued by older people in institutions (Tickle \& Yerxa, 1981). Furthermore, Madigan, Mise, and Maynard (1996) suggested that such activities provide older people not only with personal satisfaction but also with the social contact necessary for giving meaning to their lives.

Figure 1 shows the hypothetical relationships among the variables considered in this study. The three types of expectancies $\left(\mathrm{E}_{\mathrm{a}-\mathrm{a}} \times \mathrm{V}, \mathrm{E}_{\mathrm{s}-\mathrm{o}} \times \mathrm{V}\right.$, and $\left.\mathrm{E}_{\mathrm{eff}}\right)$ are defined as exogenous variables of the model. Activity, together with the mediating variables (motivation, self-efficacy, and intention), is defined as endogenous.

The upper part of Figure 1 shows motivational mediation between perceived control and activity/passivity (henceforth, the term activity will be used becausc of the positive form in which this construct was measured). We predicted the following relationships: The lower $\mathrm{E}_{\mathrm{a}-\mathrm{o}} \times \mathrm{V}$. the lower will be motivation, and, in turn, the lower the motivation, the less activity will be undertaken. This last relationship may be dircet or mediated by the explicit intention to act. As mentioned, this motivational mediation is implicit in many of the works on control.

The lower part of Figure I shows the volitional mediation between perceived control and activity. The predicted relationships are: The lower the $\mathrm{E}_{\text {eff }}$, the less self-efficacy the person will have, and, in turn, the less self-efficacy, the less activity will be undertaken.

Regarding loss of control as defined by high $\mathrm{E}_{\mathrm{s}-0} \times \mathrm{V}$, we suggest that it will affect activity negatively but there are no clcar predictions as to its mediation. Therefore, with regard to this construcl, Figure 1 includes arrows pointing to all the endogenous variables of the model.

Thus, this model proposes a relation between perceived control and activity within a single framework that integrates three forms of perceived control. These three forms of percived control are defined on the basis of differentiations 


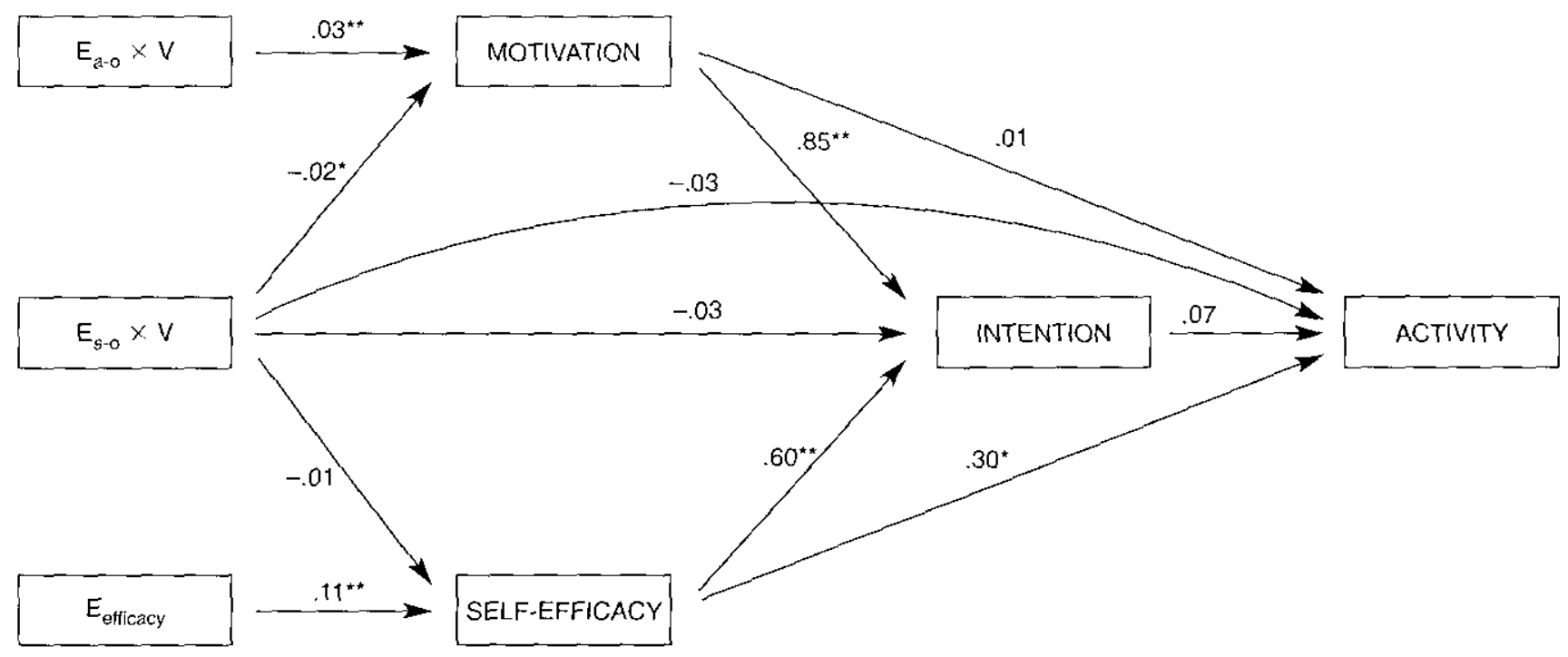

Figure I. Principal predicted associations among all the determinants, direct and indirect, of activity.

between expectancies, drawn from the literature (Bandura, 1986; Heckbausen, 1977). This integrating framework interprets the theory of planned behavior (Ajzen, 1988; Ajzen $\&$ Madden, 1986) in the light of recent developments in motivational psychology (Gollwitzer, 1991 ; Heckhausen, 1991; Kuhl, 1985). Such work has established marked differences between motivation and volition as determinants of behavior.

The present research pursues two aims. The first is to verify the differential contribution of each of the three modalities of perceived loss of control (low $\mathrm{E}_{\mathrm{a}-\mathrm{o}} \mathrm{s}$, high $\mathrm{E}_{\mathrm{s}-}$ ${ }_{s} \mathrm{~s}$, and low $\mathrm{E}_{\mathrm{eff}} \mathrm{s}$ ) to the degree of social activity engaged in by institutionalized older people. The second aim is to analyze the mediating role of motivation and volition in the effects of perceived control on action.

\section{Method}

\section{Participants}

From a total of 118 older persons, having no physical or mental handicaps, medium-to-low socioeconomic status, and institutionalized in a public old people's home in Salamanca (Spain), 102 were selected at random. Out of these, 20 participated in a prior phase of elaboration of questionnaires to be employed in the curtent study. The 82 remaining individuals participated in the data gathering phase. Of these, 56 (22 men and 34 women) filled in the questionnaire ( $70 \%$ response level). The age of the participans ranged from 68 to 98 , with a mean age of 82.02 $(S D=6.24)$. All respondents had been institutionalized for 1.3 years; $34 \%$ lived in the institution with their spouse, whereas the remaning $66 \%$ were single or widowed.

\section{Materials and Procedure}

The procedures for developing the scales and collecting data were those reported by A.jzen and Madden (1986). AII the theoretical variables shown in Figure 1 werc measured using 7-point semantic differential scales. All items were written in Spanish. To develop the itcms, a questionnaire was applied in a prior phase of the study in order to delimit the most frequent or modal beliefs. For this purpose, 20 older individuals from the same center as the final sample were selccted at random. The questionnaire items referred to: (a) the beliefs most frequently held by the older population with respect to outcomes (advantages and disadvantages) resulting from use of the reading room and attendance at the video sessions, and (b) their beliefs with respect to what facilitates or impedes them from carrying out these activities. Once the idiosyncratic or nonspecific answers had been excluded, seven outcomes (to amuse oncself, cyes become tired, to get informed, to give others the chance to annoy one, to learn something, to observe or find out about somewhat indecent matters, and not to think about sad things) and five aids/impediments (problems with eyesight, other activities, health problems, good health, and feeling sad) wcre obtained from the responses to this questionnaire.

Using these outcomes and aids/impediments, we elaborated the items corresponding to the following constructs: $\mathrm{E}_{\mathrm{a}-\mathrm{o}} \mathrm{s}$, $E_{s-0} s, V$, and $E_{e f f}$. Each item was rated on a 7-point bipolar differential semantic scale, with different poles for each constuct. (a) For the $\mathrm{E}_{\mathrm{i}-\mathrm{o}}$ items, we asked: "Attending the rading room regularly and the video sessions organized weekly will help you to ... (each of the seven outcomes)." These items were rated on a scalc ranging from very pobable $(+3)$ to very improbable (-3); (b) For the $\mathrm{E}_{s-1}$ items, wo asked; "Here, even if you don't do anything, you ... (each of the 
seven outcomes)." "These items were also rated from very probable $(+3)$ to very improbable $(-3)$; (c) For the items comesponding to the values assigned to these results $(V)$, we asked:: "For you, to (each of the seven outcomes) is ..." These ilems were rated on a scale ranging from wery good $(+3)$ to very bad (-3); and (d) For the $\mathrm{E}_{\mathrm{eff}}$ items, we asked: "How frequently do/does (each of the tive aids/impediments) help you to go/impede you from going to the reading room or to the video session?" These itens were rated on a scale ranging from yery frequently $(+3)$ to very infrequesinty $(-3)$.

Each of the $E_{a-13}$ s was multiplied by the corresponding value (V) and the sum of the products became the measure of the construct $\mathrm{E}_{\mathrm{a}-\mathrm{0}} \times \mathrm{V}$. Likewise, each of the $\mathrm{t}_{\mathrm{s}-1}$ s was multiplied by the corresponding value and the sum of the products was a measure of the construct $E_{\mathrm{x}-1)} \times \mathrm{V}$. The sum of efficacy expectancies scores served as a neasure of the construct $\mathrm{E}_{\mathrm{ctl}}$. As some $\mathrm{E}_{\mathrm{ett}} \mathrm{s}$ referred to possible impedinents and others to aids, the score of the former was reversed before adding them up.

The procedure followed by Ajzen \& Madden (1986) was also used to measure the remaining variables. Thus, to measure motivation or attitude towards participating in the indicated activities we asked the older people to evaluate the act of participation itself on four items. These ítems were also rated on 7-point scales (ranging from very good $(+3) 10$ very bad (-3); very hannful $(-3)$ to very beneficial $(+3)$; very pleasan $(+3)$ to very unpleasant $(-3)$; and very wise $(+3)$ to very foolish $(-3))$. The mean scores of these items served as a measure of the motivation construct. The internal consistency of this set of items was Cronbach's $a=.78$.

In order to measure self-efficacy, we asked the subjects to evaluate the degree of overall control they believed they had over attendance at these activities. Two items were posed at two different places in the questionnaire: "For you, going to the reading room and the video sessions is ..." was rated on a scale ranging from very easy $(+3)$ to very difficult $(-3)$. "If you want 10 , there is nothing to stop you from going" was rated on a scale ranging from very probable $(+3)$ to ver improbable $(-3)$. The mean score from these two itcms was the measure of the self-efficalcy construct (Cronbach's $a=.52$ ).

Bebavioral intentions were also evaluated with three items that appeared at different places in the questionnaire: "In spile of the fact that no one will oblige you to go, you intend to regularly go to the reading room and attend the weekly video sessions"; "Will you try to go to the reading rom and video sessions regularly?"; and "How often do you intend to carry out these activities?" These items were rated on a scale ranging from very probable $(+3)$ to very improbalble $(-3)$. The mean score of these three items was the measure of the intention construct (Cronbach's $a=.91$ ).

To measure the activity varjable, six members of the staff were asked to evaluate the erce degree of participation of the older people in the criterion activitics. The probability of each person's future participation was evaluated on at 7-point continum ranging from very probable $(+3)$ to very improbable (-3). The mean score of these six estimations was the measure of the activity construct (Cronbach's $a=87$ ). As a second measurement. we also asked the six staff members 10 assess the degree of general activity, from very active $(+3)$ to very passive $(-3)$, of each of the ofler individuals in the social activities of the center. As predicted. this sccond measurement of more gfobal activity did not afford any significant tesult. It will therefore not be taken into account in either the analyses or the discussion of the results.

\section{Results}

As a first step towards determining the relationship of the independent variables with the degree of activity, Pearson 's product-moment correlations were catculated. The intercorrclations of the variables of the study are shown in Table 1.

Table 1

Interorrelations, Means, and Standard Deviations for Vuriables

\begin{tabular}{|c|c|c|c|c|c|c|c|}
\hline Variables & 1 & 2 & 3 & 4 & 5 & 6 & 7 \\
\hline 1. $E_{1-0} \times V$ & - & & & & & & \\
\hline 2. $E_{s-10} \times V$ & -.07 & - & & & & & \\
\hline 3. $\mathrm{E}_{\mathrm{elf}}$ & .39 & .16 & - & & & & \\
\hline 4. Motivation & .39 & -.27 & .16 & - & & & \\
\hline 5. Self-Eflicacy & .11 & 0 & 48 & .10 & - & & \\
\hline 6. Intention & .28 & -.27 & .45 & .49 & .46 & $\ldots-$ & \\
\hline 7. Activity & .22 & -.27 & .29 & .16 & .38 & .33 & - \\
\hline$M$ & 9.36 & 7.11 & 6.64 & 1.57 & 1.68 & 0.76 & 0.56 \\
\hline$S D$ & 13.59 & 12.10 & 6.26 & 0.98 & 1.45 & 2.08 & 1.31 \\
\hline
\end{tabular}

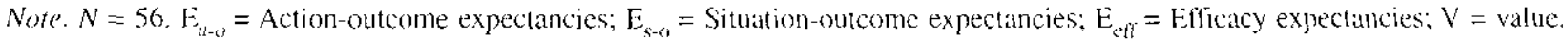
Comelations greater than 26 are significant at $p<.05$. 
Structural equation analysis for directly observed variables was used to confirm whether the path model shown in Figure I filled our data. To estimate the structural parameters, we used the maximum likelihood method (Jöreskog \& Sörbom, 1988).

Regarding goodness of fit, the following indexes indicate a good fit: $\chi^{2}=10.12, \mathrm{df}=7(p=.18) ; \chi^{2} / \mathrm{df}=1.45$, goodnessof-fit index $(\mathrm{GFI})=95$. Adjusted goodness-of-fit index $(\mathrm{AGFI})$ $=.81$, indicating a moderate fit. Thus, most of these goodnessof-fit indexes indicate that the path model of activity was supported fairly well by the data. The model accounted for $45 \%$ of the variance, although, as commented upon below, not all the ecuations have the same explanatory power.

Table 2 shows the parameter estimates corresponding to the structural model. We confirmed the predicted influence of the cxogenous variables on the endogenous ones. Thus, the $\mathrm{E}_{\mathrm{a}-\mathrm{o}} \times \mathrm{V}$ expectancies signiticantly affected motivation. and $E_{\text {eff }}$ significantly affected self-efficacy. As regards the $\mathrm{E}_{\text {s-o }} \times \mathrm{V}$ cxpectancies, for which we did not find any clear predictions in the literature, these affected motivation but had no effect on self-efficacy. Nor did this variable either significantly affect intention or activity. Motivation accounted for $21 \%$ of the variance, and self-efficacy, $24 \%$.

With respect to the endogenous variables of the model, motivation and self-efficacy both significantly alfected intention, accounting for about $40 \%$ of its variance. In turn, self-efficacy affected activity but not intention or motivation.

Taken as a whole, the pattern of results seems to support a volitional mediation of perceived behavioral control over activity, rather than a motivational mediation. The greater the perceived behavioral control, defined in terms of high expectancies of efficacy, the greater the older person's selfeflicacy, and more social activity will be engaged in. In turn, perceived behavioral control, defined in terms of $\mathrm{E}_{\mathrm{a}-\mathrm{0}}$ and $E_{s-1,-1}$ affects motivation: the higher the $E_{\mathrm{a}-0)}$ or the lower the $\mathrm{E}_{\mathrm{s} \rightarrow 0}$, the higher will be the older person's molivation towards such activitics. However, greater motivation does not correspond to more activity: Motivation did not significantly affect activity.

Strangely, the explicit intention to engage in an activity did not prove to be a good predictor of the older person's actual behavior, which means that the activities studied here, although simple, do not seem to be under their volitional control. Taken together, the endogcnous variables and the variable $E_{s-0} \times V$ accounted for $22 \%$ of the tolal variance of activity.

As the previous statistical analyses were somewhat questionable, given the small sizc of the group, complementary analyses were carried out using the same data. Specifically, we used hierarchical regression models to test our hypotheses concerning the relations presented in Figure 1. Guided by these hypotheses, we performed three different hierarchical regression analyses. Firstly, we analyzed the contribution of the molivational path to account for activity. For this purpose, the independent variables were included in the following steps: (a) $\mathrm{E}_{\mathrm{a}-\mathrm{o}} \times \mathrm{V}$, (b) motivation, and (c) intention. Secondly, we analyzed the contribution of the volitional path to account for activity. For this purpose, the independent variables were entered in the following

Table 2

Path Coefficients and Goodness-of-Fit Indexes for the Model Depicted in Figure I

\begin{tabular}{|c|c|c|c|c|}
\hline \multirow{2}{*}{ Independent Variables } & \multicolumn{4}{|c|}{ Dependent Variables } \\
\hline & Motivation & Self-Efficacy & Intention & Activity \\
\hline \multicolumn{5}{|l|}{ Endogenous } \\
\hline Motivation & & & $.85^{* * a}$ & .01 \\
\hline Self-Efficacy & & & $.60^{* * * * *}$ & $.30^{*}$ \\
\hline Intencion & & & & .07 \\
\hline \multicolumn{5}{|l|}{ Exogenous } \\
\hline$E_{t a r b} \times V$ & $.03 * * h$ & & & \\
\hline$E_{s-0} \times V$ & $-.02^{*}$ & -.01 & -.03 & -.03 \\
\hline $\mathrm{E}_{\mathrm{efl}}$ & & $.11^{* * * 4}$ & & \\
\hline$R^{2}$ & $2 I^{\circ}$ & .24 & .43 & .22 \\
\hline \multicolumn{5}{|l|}{$R^{2}=.45^{1}$} \\
\hline \multicolumn{5}{|l|}{$x^{2}(7)=10.12$} \\
\hline \multicolumn{5}{|l|}{$x^{2 / d f}=1.45$} \\
\hline \multicolumn{5}{|l|}{$\mathrm{GFl}=.95$} \\
\hline $\mathrm{AGFI}=.81$ & & & & \\
\hline
\end{tabular}

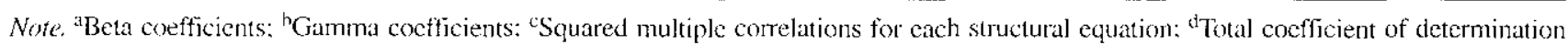
for all structural equations. GFl = goodness-of-fit index; AGlil = adjusted goodness-of-fit index; $\mathrm{I}_{\mathrm{d}-\mathrm{s}}=$ Action-outcome expectancies: $\mathrm{E}_{\mathrm{s}, \mathrm{l}}=$ Situation-outcome expectancies; $\mathrm{E}_{\mathrm{c} \mathrm{fl}}=$ Efficacy expectancies; $\mathrm{V}=$ value.

$* p<0.05, * 0<01$. 
Table 3

Hierarchical Regression Analysis Predicting Activity with $E_{\text {atr }} ;$ Motivation, and htention

\begin{tabular}{|c|c|c|c|c|c|}
\hline Step and Predictor Variable & $B$ & $S E$ & $\beta$ & $R^{2}$ & $\Delta R^{2}$ \\
\hline \multicolumn{6}{|l|}{ Step 1} \\
\hline $\mathrm{E}_{\mathrm{di}-1,3} \times \mathrm{V}$ & 0.02 & 0.01 & .22 & .05 & .05 \\
\hline \multicolumn{6}{|l|}{ Step 2} \\
\hline$E_{i-10} \times V$ & 0.02 & 0.01 & .19 & & \\
\hline Motivation & 0.11 & 0.19 & .09 & .05 & .00 \\
\hline \multicolumn{6}{|l|}{ Step 3} \\
\hline$E_{i-0} \times V$ & 0.01 & 0.01 & .15 & & \\
\hline Motivation & -0.07 & 0.21 & -.05 & & \\
\hline Intention & 0.19 & 0.09 & $.31 \div$ & .13 & $.07^{*}$ \\
\hline
\end{tabular}

Note. $\mathrm{E}_{\mathrm{a}-\mathrm{a}=}$ Action-outcome expectancies; $\mathrm{V}=\mathrm{vat}$ me, $*_{p}<.05$.

steps: (a) $\mathrm{E}_{\mathrm{eff}}$ (b) self-efficacy, and (c) intention. Thirdly, we analyzcd whether the explanatory capacity of the mode] increases when $\mathrm{E}_{s-\gamma} \mathrm{s}$ are introduced in an equation in which the mediating variables of the model were included (intention, self-efficacy, and motivation). lhis involved entering the independent values in the following steps: (a) intention, self-efficacy, and motivation; and (b) $\mathrm{E}_{\mathrm{s}-\mathrm{s}} \times \mathrm{V}$. In each of the hicrarchical regressions, the changes in the $R^{2}$ and the $\beta$ values were verified.

The results obtained were similar to those described previously. As shown in Table 3 , the $\mathrm{E}_{\mathrm{it}-0}$ s did not significantly account for the variability in activity, $F(1,54)=2.73, p=$ ns. Entering motivation in the second step did not add predictive power, $F_{\text {change }}(1,53)=0.35, p=n s$. Entering the intention variable in the third step, however, did contribute significantly, $F_{\text {change }}(1,52)=4.30, p<05$, although the equation with the three independent variables did not reach significance, $F(3,52)=2.51, p=u s$. The variables of the motivational path accounted for $13 \%$ of the total variance, of which $7 \%$ corresponded to intention and the remaining $5 \%$ corresponded to the variables $E_{a-0} \times V$ and Motjvation.

As can be seen in Table 4, the second hicrarchical regression showed that the variables comprising the volitional path signiljeantly predicted activity, $F(3,52)=3.78, p<.05$. The self-efficacy variable contributed especially to this prediction, its entry into the second step having increased the prediction power of $\mathrm{E}_{\mathrm{cff}}$ alone. $F_{\text {change }}(1,53)=4.73, p<.05$. Both variables contributed significantly to variability in activity, $F(2,53)=5.01, p<.05$. Comparison of the regression coeflicients obtained in the first and second steps reveals the mediating role of self-efficacy between $\mathrm{E}_{\text {cif }}$ and activity. In other words, the effects of $E_{\text {efl }}$ on activity are indirect, via the self-efficacy variable. Lastly, entering intention in the third step did not add predictive power to the equation, $F_{\text {change }}(1$. $52)=1.26, p=n s$. The variables of the volitiona] path accounted for $18 \%$ of the total variance. This percentage is almost entirely due to the variables $\mathrm{E}_{\text {elf }}$ and self-efficacy $(16 \%)$, with a negligible contribution of the variable intention $(2 \%)$.

Table 4

Hierarthical Regression Analysis Predicing Activity with $E_{c f}$ Self-efficacy, and Intention

\begin{tabular}{|c|c|c|c|c|c|}
\hline Step and Predictor Variable & $B$ & $S E$ & $\beta$ & $R^{2}$ & $\Delta R^{2}$ \\
\hline \multicolumn{6}{|l|}{ Step 1} \\
\hline $\mathrm{E}_{\mathrm{etl}}$ & 0.06 & 0.03 & $.29^{*} *$ & $.08 *$ & $.08 *$ \\
\hline \multicolumn{6}{|l|}{ Step 2} \\
\hline$E_{\mathrm{eff}}$ & 0.03 & 0.03 & .14 & & \\
\hline Self-efficacy & 0.28 & 0.13 & $.31 *$ & $.16^{*}$ & $.08 *$ \\
\hline \multicolumn{6}{|l|}{ Step 3} \\
\hline $\mathrm{E}_{\mathrm{tff}}$ & 0.02 & 0.03 & .09 & & \\
\hline Self-efficacy & 0.23 & 0.14 & .26 & & \\
\hline Intention & 0.10 & 0.09 & .16 & $.18 *$ & .02 \\
\hline
\end{tabular}

Note. $\mathrm{E}_{\mathrm{e} \text { if }}=$ Eflicacy cxpectancies.

${ }^{*} p<.05$. 
The third hierarchical regression analysis (see Table 5) showed that the three mediating variables in the theoretical model (intention, self-efficacy, and motivation) significantly predicted activity, $F(3,52)=3.67, p<05$. Entering the $\mathrm{E}_{8 \mathrm{r}}$ $s$ in the second step only marginally increased the predictive power of the variables in the equation, $F$ change $(1,51)=$ $3.26, p=n s$. The total accounted-for variance in the measure of activity was $22 \%$, to which the endogenous variables contributed $17 \%$ and $\mathrm{E}_{5-0} \times \mathrm{V}$ only added $5 \%$

Thus, with a statistical andysis that is not so dependent on the size of the sample, wc obtained results similar to the structural equation model. The regression equation of activity on the motivational variables $\left(\mathrm{E}_{\mathrm{d}-0} \times \mathrm{V}\right.$, motivation, and intention) was not significant. However, the regression of activity on the volitional variables ( $E_{\text {eff }}$, self-efficacy, and intention) was significant, but intention did not contribute anything to the equation. Hence, it seems that sclf-efficacy has direct effects on activity and no indirect effects via intention. Lastly, the inclusion of $\mathrm{E}_{5-0} \times \mathrm{V}$ in the regression of activity on the endogenous variables of the model did not add predictive value to the equation.

\section{Discussion}

This research contributes new data in favor of the relationship between perceived control and the degree of participation in social activities among institutionalized older people. Many empirical studies have shown that this kind of participation contributes to their physical and mental wellbeing (Lai \& McDonald, 1995, Menec \& Chipperfield, 1997; Yamada, 2000). More important, this research shows that not all types of perceived control affect behavior equally, thus having implications for possible mediation.

The results obtained are contrary to a motivational mediation between perceived control and activity. Motivation does not seem to have any effect on activity, either direct or mediated by intention. The variability in activity cannot be explained by the differences in motivation towards the activity. That is, the greater or lesser interest shown by the older individuals towards the activities in question did not prove to be a good predictor of their involvement in these activities.

According to the predictions of the model, motivation depends in turn on the $\mathrm{E}_{\mathrm{a}-\mathrm{0}} \times \mathrm{V}$ products and also on the $E_{\mathrm{s}-\mathrm{o}} \times \mathrm{V}$ products, about which we had no clear prediction, athough in the second case, the relation was negative. Therefore, the definition of loss of perceived control that affects motivation (low $\mathrm{E}_{\mathrm{a}-\mathrm{r}}$ ) does not seem to have any consequences on behavior. All of this is contrary to the assumed sequence of perceived loss of control $\rightarrow$ motivational deficit $\rightarrow$ performance deficit.

However, the results are in accordance with a volitional mediation between perceived control and activity. Selfefficacy, as the estimated capacity for carrying out the activities under consideration, proved to be a good predictor of involvement in these activities. It is a direct effect, not mediated by intention. This means that the activities in question are not under total volitional control. The performance of the activities depends not so much on intention as on limilations that are beyond the individual's control. These limitations, as we shall discuss shortly, are reflected in the beliefs underlying self-efficacy (i.c., in the $\left.\mathrm{E}_{\mathrm{eff}}\right)$. Furthermore, it is reasonable to assume that perceptions of efficacy correspond more or less accurately to the real efficacy that the older person has in this situation. After all, these were daily activities about which the older people had precise knowledge and could therefore estimate their degree of efficacy with a fair degree of accuracy.

Self-efficacy in turn depends on the $\mathrm{E}_{\mathrm{eff}}$, according to the prediction of the model. On the other hand, self-efficacy has no relation with the $E_{s-0} \times V$ products. Therefore, loss of perceived control, understood as low $\mathrm{E}_{\mathrm{eff}}$, did seem to affect activity. These expectancies mainly revolve around one's physical limitations (e.g., illness, sensory loss, etc.) and emotional upsets (e.g., grief over the loss of a loved

Table 5

Hierarchical Regression Analysis Predicting Activity with $E_{e f f^{p}}$ Motivation, Intention, and $E_{\mathrm{s}-\mathrm{o}} \times V$

\begin{tabular}{|c|c|c|c|c|c|}
\hline Step and Predictor Variable & $B$ & $S E$ & $\beta$ & $R^{2}$ & $\Delta R^{2}$ \\
\hline \multicolumn{6}{|l|}{ Step 1} \\
\hline Self-efficacy & 0.27 & 0.13 & $.30^{*}$ & $.08^{*}$ & $.08 *$ \\
\hline Motivation & 0.06 & 0.20 & .04 & & \\
\hline Intention & 0.11 & 0.10 & .17 & $.17^{*}$ & $.17 *$ \\
\hline \multicolumn{6}{|l|}{ Step 2} \\
\hline Self-efficacy & 0.30 & 0.13 & $.33^{*}$ & & \\
\hline Motivation & 0.11 & 0.19 & .01 & & \\
\hline Intention & 0.07 & 0.10 & .11 & & \\
\hline$E x \underline{V}$ & -0.03 & $0.0 \mathrm{I}$ & -.24 & $.22^{* *}$ & .05 \\
\hline
\end{tabular}

Note. $\mathrm{E}_{\mathrm{s}-\mathrm{o}}=$ Situation-ontcome expectancies: $\mathrm{V}=$ value.

$p<.05$. 
one). In other words, older people worry about things that are beyond their control, as other researchers have poitued out (e.g., Nurmi et al., 1992). The present study furthermore shows that this concern may have negative effects on. behwvior, as it reduces ofder people's belief in their own capacities. Such effects are especially notable because they become gencralized to activities that are unrelated to the areas, resulting in a loss of volitional control over apparently simple activities.

An interesting result from this reseatch was the lack of association between the intention of carrying out activities and their actual performance. Thus, although motivation and self-efficacy both contribute to forming an intention, only self-cllicacy contributes to the action itself. That is, whether or not the intention formed is translated into a manifest activity seems to depend on the older people's contidence in their own capacities and not on motivation or interest in the activity.

Based on the criterion of the proportion of accountedfor variance, the best defined relation is that found between the three most global constructs: motivation, self-efficacy, and intention. The first two account for about $40 \%$ of the variance in the intention to participate. However, we obtained more modest percentages in the remaining têtevith relationis of the model. On the one hand, only $21 \%$ of the variability in motivation and $24 \%$ of the variability in self-efficacy are accounted for by a set of more specific beliefs about participation. On the other hand, only $22 \%$ of the variance in activity is accounted for by the variables of the model. This percentage drops to $16 \%$ if we only consider the two variables with the highest predictive power for activity: $\mathrm{E}_{\text {eft }}$ and self-efficacy. Doubtless, a larger number of participants and more refined assessment instruments would have increased the precision of the proportions of accounted-for variance. Nevertheless, we believe that the model's elegance, with a reduced number of variables, must forfeit some accounted-for variance, especially when the model is applied to such complex behavior.

It can be concluded from the present study that motivating ofder people towards social activitics is nor a very useful way to get them involved. On the contrary, it is clear that interventions aimed at making the most of older people's abilities are more useful.

When human factors are analyzed, a similar conclusion is drawn. In this sense, Czaja (1997) pointed out that the difficulty that older people have in functioning effectively in a residential environment might be related to the disparity between the environmental demands and their ability to meet those demands. Such a disparity could increase in institutional environments. At least, the level of activity in general and of participation in social behavior in particular observed in institutional environments is less than in noninstitutional environments. (Madigan el al., 1996).

Skinner (1996) expressed regret that expectancies of efficacy and of action-outconse were rarely measured in the same research work. From the point of view of intervention. she argued, it is fundanemal to take into account the way that both aspects affect behavior. Only then can the implications for a correct intervention aimed at optimizing comtrol be drawn. In this sense, the data from our stady suggest that intervention should be aimed at affecting belicfs related to selfeflicacy and not so much at belicl's related to the contingency between behivior and its results.

The same thing can be said of the $E_{s-6}$ s. These are rately studied simultancously with the $\mathrm{E}_{\mathrm{a}-0}$ s (or with the $\mathrm{E}_{\mathrm{eff}} \mathrm{s}$ ), and hence. very little is known about them. In the present study, into which they were introduced for exploratory purposes, they had no effect cither on hehavior or on selfefficacy, although they did show an effect on motivation. Another consideration is the joint effect of both types of expectancies, although this was not analyzed in the present study. Indeed, separately, low $E_{\mathrm{a}-13}$ sor high $E_{\mathrm{s}-\mathrm{i}}$ s both imply a lack of perceived control and low motivation. However, taken together (low $\mathrm{E}_{\mathrm{a}-1}$ s and high $\mathrm{E}_{5-4} \mathrm{~s}$ ), they form a type of passive control whose relation with behavior (and even with motivation) may be different from the mere lack of contingency (i.e., low $\mathrm{E}_{\mathrm{a}-\mathrm{y}} \mathrm{s}$ ). What effects could the belief that "it is easier to obtain what I want by not acting rather than by acting" have on behavior?

There has been some controversy over whether such passive control is beneficial for older people. Baltes and Wahl (1992) identified a type of passive control that is very frequent in institutional envitomments: that established between the older person's dependent behavior and the staff's social attention and support. Dependent behavior could help the older individual to build a more manageable and predictable social/affective environment. In contrast, however, this behavior could, in the long run, favor decline as the skills that the older person still has fall into disuse. In this sense, one of the factors limiting the benefits of passive forms of control may be the older person's own level of confidence (Baltes \& Wahl, 1992; Parmelee \& Lawton, 1990).

Beyond the implications for intervention, the results of this research have theoretical relevance. In the tirst place, they have inplications for a differential conception of effictey and $\mathrm{E}_{\mathrm{a}-\mathrm{o}}$ s. In an educational context, it has been pointed out that both $E_{\text {at } 6}$ s and $E_{e f} s$ affect the choice between alternatives, but $\mathrm{F}_{\text {in }}$ salso affect the individual's effort and willingness to persist in the face of difficulties (Pintrich \& Schunk, 1996). The results of the present reseatch corroborate this differentiation in a completely different sphere from the educationai one. Both types of expectancies affected willingrtess to behuve in a centain way, but only high $E_{\text {alr }}$ s determined whether this tehavior, which required some effort on the part of the person, was carrica out.

Secondly. the resuls of this rescarch have implications for $\mathrm{E}_{s-4}$ s (Hech hasen, 1977). These affected motivation segallively, but had no efted on selfefficacy. Tlat is, the belief that they can obtain valued results without having to do anything seems to de-motivate persons but does not seem 
to affect their belief in their capacity to behave as required. Thus, this type of expectancy had no effects on types of behavior that required some competence on the part of the person. However, and given the scurcity of research on this type of expectancy, several considerations might be taken into account for future studies. On the one hand, it is possible that the relation between $\mathrm{E}_{\mathrm{s-1} /} \mathrm{s}$ and $\mathrm{E}_{\mathrm{e} / \mathrm{f}^{\mathrm{s}}}$ is not onc of allor-none, but rather a gradual relation, according to the older person's current degree of dependence on the staff or on other people. Alternatively, $\mathrm{E}_{\mathrm{s}-5}$ s may be related 10 agent end belicfs when the causal agent of the result does not refer to the self but to other persons. On the other hand, it is possible that the relation between $E_{s-0} s$ and activity may depend on the type of activity considered.

Thirdly, the results of this research provide support for a general theoretical model whose sphere of application is not limited to the type of behavior studied here. The model, which takes into account three belicfs related to control and two possible mediational paths, could be used to study other types of behavior and in different contexts. Thus, for example, the variables of the model could function in a diflorent way from the way they functioned here with types of behavior that are under volitional control. In this sense, it would be interesting 10 analyze the role of motivation and its antecedents $\left(E_{i-0}\right.$ s and $E_{s-0} s$ ) in that type of behavior.

Summing up, the loss of perceived control seems to affect activity-passivity, but this occurs when the loss of control occurs as a consequence of low self-efficacy expectancies, which produce low self-efficacy. In contrast, the loss of control caused by low $\mathrm{E}_{\mathrm{a}-\mathrm{O}}$ s and high $\mathrm{E}_{\mathrm{s}-\mathrm{o}} \mathrm{s}$, which produce low motivation, does not seem to affect passivity. This pattern of results climinates the assumed motivational mediation of the effects of perceived control on passivity, supporting instead a volitional mediation between control and passivity.

In all, these conclusions are provisional in that they do not eliminatc alternative interpretations of the data. First, it is possible that some of the variables of the model did not appear to affect activity because of the way in which the variable was measured. It is likely that the staff, when estimaling the degree of the older person's involvement in the activities studicd, would be considering relatively long periods of time and not necessarily the interval immediately following questionnaire response. Therefore, in order to eliminate this possibility, new data should be obtained in which the expressions of beliefs were uncquivocally prior in time to the activity studied.

Sccond, the habitual mistrust of institutionalized older people may have affected their responses to the questionnaire. However, given that the items referjed to noncompromising issues (belicfs about daily behavior), this is unlikely.

Lastly, a clarification is in order regatding the role of motivation that we bave nutlined above. In this research we refer exclusively to extrinsic motivation, that is, motivation caused by the outcome that a person hopes to achicve. This kind of motivation has no incidence on the behavior measured. However, there is another form of motivation. intrinsic motivation (Deci \& Ryan, 1985), whose role has not been cxplored in this study. Intrinsic motivation depends on the degree of self-determination, competence, and challenge that an activity arouses in the person. Some studies have, in fact, shown that the intrinsic motivation felt by older people in leisure activitics contributes to psychological welfare (Caltabiano, 1995; Iso-Ahola \& Park, 1996) and to life satisfaction (Guinn, 1999). Thus, planning intervention strategies aimed at inducing intrinsically motivated participation opens up interesting allernative paths other than those considered here. It would be a matter of generating activities to produce feelings of autonomy and competence in older pcople whilc, at the same time, comprising a challenge.

\section{References}

Abeles, R.P. (1991). Sense of control, quality of life and frail older people. In J. E. Birren, J.E. Lubben, J. C. Rowe, \& D.E. Destchman (Eds.), The concept and measurement of quality of life in the frail ederly (pp. 297-314). San Diego, CA: Academic Press,

Ajzen, [. (1988). Antudes, personality, and behavior. Homewood, IL: Dorsey Press

Ajzen, I., \& Madden, T.J. (1986). Prediction of goal-directed behavior: Attitudes, intentions, and perceived behavioral control. Journal of Experimental Social Psychology; 22. 453-474.

Arbuckle, T.Y.. Pushkar, D., Chaikelson, J.. \& Andres, D. (1999). Coping and control processes: Do they contribute to individual differences in health in older adults? Canadian Joumal on Aging, 18, 285-312.

Baltes. M.M., \& Baltes, P.B. (Eds.). (1986). The psychology of control and aging. Hillsdale, NJ: Eribaum.

Baltes, P.B., \& Baltes, M.M. (Eds.). (1990). Successful aging. Perspectives from the behavioral sciences. Cambridge, MA: Cambridge University Press.

Baites, M.M., \& Reisenzein, R. (1986). The social world in longterm care institutions: Psychosocial control toward dependency? In M.M. Baltes \& P.B. Baltes (Eds.), The psychology of control and aging (pp. 315-343). Hillsdale, NJ: Erlbaum.

Battes, M M., \& Wahl, H.-W. (1992). The dependency-support seript in institutjons: Generalization to community settings. Prychology and Aging, 7, 409-418.

Bandura, A. (1977). Self-efficacy: Toward a unifying theory of behavioral change. Psychological Review, 84, 286-303.

Bandura, A. (1982). Self efficacy mechantsm in human agency. American Psychologist, 37, 122-147.

Bandura, A. (1986). Social foundations of though and action: A social cognitive theory. Englewond Cliffs. NJ: Prentice Hall.

Bandura. A. (1991). Self-regulation of motivation through anticipatory and self-feactive mechanisms. In R. A. Dienstbict (Ed). Perspectives on motination (Pp. 69-164). Lincoln, NE: University of Nebraska Press. 
Brandestädter, $J$., \& Renner, G. (1990). Tenacious goal pursuit and flexible goal adjustment: Explication and age-related analysis of assimilative and accommodative models of coping. Psychology and Aging, 5, 58-67.

Caltabiano, M. (1995). Main and stress-moderating health benefits of leisure. Society and Leisure, 18, 33-52.

Chen, C. (2001). Aging and life satisfaction. Social Indicators Research, 54, 57-79.

Chou, K.L., \& Chi, 1. (2001). Financial strain and depressive symptoms in Hong Kong elderly Chinese: The noderating or medjating effect of sense of control. Aging and Mental Health, $5,23 \times 30$.

Czaja, S. J. (1997). Using technologies to aid the performance of home tasks. In A. D. Fisk \& W. A. Rogers (Eds.), Handbook of human factors and the older adult (pp. 311-334). San Diego, CA: Academic Press.

Deci, E., \& Ryan, R. (1985). Inirinsic motivation and selfdetermination in human behavior: New York: Plenum.

Feather, N.T. (Ed.). (1982). Expectations and actions: Expectancyvalue models in psychology. Hillsdale, NJ: Erlbaum.

Fry, P.S. (Ed.). (1989). Psychological perspectives of helplessness and control in the elderly. Amsterdam: North-Holland.

Gollwitzer, P. M. (1991). Abwägen und Planen. Göttingen, Germany: Hogrefe.

Gollwitzer, P. M. (1993). Goal achievement: The role of intentions. In W. Stroebe \& M. Hewstone (Eds.), European review of social psychology (Vol. 4, pp. 141-185). London: Wiley.

Guinn, B. (1999). Leisure behavior motivation and the life satisfaction of retired persons. Activities, Adaptation and Aging, $23,13-20$.

Heckhausen, H. (1977). Achievement motivation and its constructs: A cognitive model. Motivation and Emotion, 1, 283-329.

Heckhausen, H. (1991). Motivation and action. Berlin: SpringerVerlag.

Heider, F. (1958). The psychology of interpersonal relations. New York: Wiley.

Iso-Ahola, S., \& Park, C. (1996). Leisure-related social support and self-determination as buffers of stress-illness relationship. Journal of Leisure Research, 28, 169-187.

Jöreskog, K.G., \& Sïrbom, D. (1988). LISREL 7: A guide to the program and applications. Chicago, ll. SPSS.

Karoly, P. (1993). Mechanisms of self-regulation: A systems view. Annual Review of Psychology, 44, 23-52.

Krause, N. (1994). Stressors in salient social roles and well-being in later life. Jownd of Gerontology: Psychological Sciences, 49. P137-P148.

Krause, N., \& Shaw, B.A. (2000). Role-specitic feelings of control and mortality. Psychology and Aging, 15, 617-626.

Kuhl, J. (1985), Votitional mediators of cognition-behavior consistency: Self-regulatory processes and action versus state orientation. In J. Kuhl \& J. Beckmann (Eds.), Action control: From cognition to behavior (pp. 101-128). Berlin: SpringerVerlag.

Kuh]. J. (1986). Aging and models of control: The hidden costs of wisdom. In M.M. Baltes \& P.B. Baltes (Eds.), The psychology of control and aging (pp. [-33). Hillsdale, NJ: Eribaum.

Lachman. M.E. (1986). Locus of control in aging rescarch: A case of multidimensional and domain-specific assessment. Joumal of Prychology and Aging, I. 34-40.

Lai, D., \& McDonald, J. R. (1995). Life satisfaction of Chinese elderly immigrants in Calgary. Cancedian Joumal on Aging, 14, 536-552.

Maddox. G. L., \& Lawton, M. P. (Eds.). (1988). Varieties of aging. Annual Review of Geronology and Geriatrics (Vol, 8). New York: Springer-Verlag.

Madigan, M. J., Mise, D.H., \& Maynard, M. (1996). Life satisfaction and level of activity of male elderly in institutional and community settings. Activifies, Adaptation and Aging, 21, 21 36.

Mateos. P.M. (1996) Motivación. intención y acción. In 1. Garrido (Ed.). Psicologia de la motivación (pp. 69-96). Madrid: Síntesis.

Menec, V.H., \& Chipperfield, J.G. (1997). Remaining active in later life: The role of locus of control in senior's leisure activity participation, health, and life satisfaction. Joumal of Aging and Healh, 9, 105-125.

Nelson, E.A., \& Dannefer, D. (1992). Aged heterogeneity: Fact or fiction? The fate of diversity in gerontological research. The Gerontologist, 32, 17-23.

Nurmi, J., Pulliainen, H., \& Salmela-Aro, K. (1992). Age differences in adults' control beliefs related to life goals and concerns. Psychology and Aging. 7, 194-196.

Parmelee, P.A., \& Lawton, M.P. (1990). The design of special environments for the aged. In J.E. Birren \& K.W. Schaje (Eds.), Handbook of the prychology and aging (pp. 465-488). San Diego, CA: Academic Press.

Perrig, C.P. (2000). Control beliefs, health, and well-being in elderly. In W.J. Perrig \& A. Grob (Eds.), Control of human behavior, mental processes and consciousness, Essays in honor of the $60^{\text {h }}$ birthday of August Flammer (pp. 411-423). Mahwah, NJ: Er[baum.

Pintrich, P.R., \& Schunk, D.H. (1996), Motivation in education. Theory, research, and applications. Englewood Cliffs. NJ: Prentice Hall.

Rodin, J., \& Langer, E. J. (1977). Long-term effect of a controlrelevant intervention with the institutionalized aged. Joumat of Personality and Social Psychology, 35, 897-902.

Rodin, J., \& Timko, C. (1991) Sense of control, aging, and bealth. In M.G. Ory, R.P. Abeles. \& P.D. Lipman (Eds.), Aging, health, and behavior (pp. 174-206). Newbury Park, CA: Sage.

Rothbaum, F., Weisz, J., \& Snyder, S. (1982). Changing the world and changing the self: A two-process model of perceived control. Journal of Personality and Socinl Psychology, 42, 5-37.

Schulz. R. (1976). The effects of control and predictability on the psychological and physical well-being of the institutionalized aged. Jommal of Personality and Social P.ychology, 33, 563573.

Schulz, R. (1986). Successful aging: Balancing primary and secondary control. Adult Development and Aging News, 13,24. 
Schulz, R., Heckhausen, J., \& Locher, J. (1991). Adult development, control, and adaptative functioning, Journal of Social Issues, 47, 177-196.

Shaw, B. A., \& Krause, N. (2001). Exploring race variations in aging and personal control. Journals of Gemntology: Series B: Psychological Sciences and Social Sciences, 56B. S119S124.

Skinner, E.A. (1996). A guide to constructs of control. Journal of Personality and Social Psychology; 71, 549-570.

Tickle, L.S., \& Yerxa, E.J. (1981). Need satisfaction of older persons living in the community and in institutions. Part 2: Role activity. American Joumal of Occupational Therapy, 35, 650-655.
Wrosch, C., Heckhausen, J., \& Lachman, M.E. (2000). Primary and secondary control strategies for managing health and tinancial stress across adulthood. Psychology and Aging, 15, 387-399.

Yamada, N. (2000). The relationship between leisure activities, psycho-social development and life satisfaction in late adulthood. Japanese Joumal of Developmental Psychology, $11,34-44$.

Received December 28, 2000 Revision received July 18,2001 Accepted October 16, 2001 